\title{
Consideration of hydraulic limitations in setting the mode parameters of combined piercing the holes
}

\author{
Svetlana Vasilevskaya ${ }^{1 . *}$ \\ ${ }^{1}$ Novosibirsk State Technical University, Faculty of Mechanical Engineering and Technologies, \\ 630073 Prospekt K. Marks 20, Novosibirsk, Russia
}

\begin{abstract}
The paper considers the hydrodynamic limitations in the combined machining, caused by the non-rigidity of the tubular cathodetool. It is shown that increasing the inertia moment of the cathode-tool cross section is possible only in decreasing the diameter of the hole for pumping the electrolyte. It should be noted that reducing the diameter of the hole increases the hydrodynamic losses of the electrolyte flow in the hydraulic path and, as a result, leads to a significant reduction in the range of the mode regimes. Thus, to implement the combined piercing of deep holes of small diameter, it is necessary to quantify the hydrodynamic limitations in using the tubular cathode-tool of significant length to establish the mode parameters.
\end{abstract}

\section{Introduction}

Modern problems of forming the surfaces of small diameters are connected, first of all, with developing small parts both in traditional branches of machine building, tool engineering, automobile industry, aircraft engineering and in medicine - in creating different types of prosthetic implants. The operation conditions often impose limitations on choosing the part material, predetermining the use of high strength, corrosion-resistant and other materials [1 - 5]. The necessity of forming the surfaces of small diameters in materials difficult to process excludes the possibility of using traditional methods of processing, particularly the methods of mechanical cutting. The choice of forming technologies connected with electromachining processes of removing the material is becoming vital [2, 3]. Laser, electron beam, plasma, electro-erosion, electrochemical and other methods of machining metals and alloys of different types have been developed most of all [6, 7].

The specific place among technological tasks mentioned above belongs to forming the holes, the diameter of which is limited by the dimension range to $1 \mathrm{~mm}$ and the holes depth exceeds its 10 diameters.

\footnotetext{
* Corresponding author: vasilevskaya@corp.nstu.ru
} 
Papers [8, 9] show the perspective of using the combined method of forming based on electrochemical and electro-erosion processes. It is proved experimentally that due to the electrochemical process it is possible to use the electro-erosion component in implementing high-voltage pulses in the inter-electrode gap when the electrolyte is the technological medium.

Electrochemical forming of deep holes with a small diameter is accompanied by appearing hydrodynamic limitations connected with the loss of the electrolyte flow pressure on the local resistances of the hydraulic path [10]. The appearance of hydrodynamic limitations is expressed in considerable narrowing the mode parameters area of the electrochemical process and reducing the maximum achievable depths of the hole piercing.

Paper [10] shows the role of the electro-isolation layer thickness on the side of the cathode-tool for strengthening hydrodynamic limitations during the electrochemical piercing of the holes.

Besides, the breakdown of the electrochemical process stability of the deep holes piercing appears because of the oscillation excitations of the cathode-tool. As a result, short circuits appear in the inter-electrode gap.

The oscillations of the non-rigid cathode-tool which is a hollow tubular electrode with a length exceeding considerably its diameter are due to the movement of the hydrodynamic flow in the inter-electrode gap. The fact leads to the damage of not only the cathode-tool (Fig. 1) but also of the surface of the processed hole.

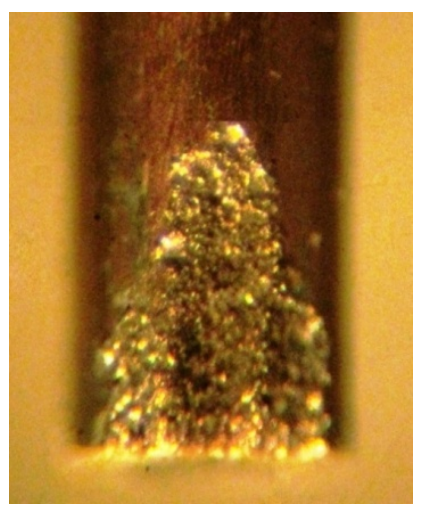

Fig. 1. Defect on the side of the cathode-tool in appearing short circuits in the side inter-electrode gap during the electrochemical piercing of the hole

The paper under consideration is devoted to studying the influence of limitations in processing, caused by the non-rigidity of the cathode-tool, and to the quantitative evaluation of the mode regimes both for electrochemical and combined piercing of deep holes of small diameter.

\section{Experimental Methods}

Paper [10] presents the results of calculating the boundaries of the mode parameters area of the electrochemical piercing of the hole in copper M1 in $20 \%$ aqua solution of $\mathrm{NaNO}_{3}$ by the hollow cathode-tool with the diameter ratio of $0.28 / 0.18 \mathrm{~mm}$ and the lines of maximum achievable depths of the hole piercing.

The use of a considerable (in comparison with the diameter) length leads to appearing the lateral oscillations in processing the cathode-tool deep holes. It takes place under the influence of the flow hydrodynamics, which amplitude can be expressed as follows: 


$$
f=\frac{F \bullet l^{3}}{3 E I},[\mathrm{~mm}]
$$

where $F$ - the acting force on the cathode-tool, N;

$l$ - the length of the cathode-tool, mm;

$E$ - the module of the material rigidity, $\mathrm{N} / \mathrm{mm}^{2}$;

$I$ - the inertia moment of the cross section, $\mathrm{mm}^{4}$.

Reducing the oscillation amplitude of the cantilevered cathode-tool in the current machining conditions is possible only in increasing the inertia moment (I) of its cross section. Taking into account the tubular shape of the cathode-tool, the inertia moment of its cross section can be presented as:

$$
I=\frac{\pi}{64}\left(D_{K}^{4}-d^{4}\right),\left[\mathrm{mm}^{4}\right],
$$

where $D_{k}$ - the outside diameter of the cathode - tool metal part;

$d$ - the diameter of the hole in the cathode - tool.

\section{Results and Discussion}

Increasing the inertia moment of the instrument cross section of the tubular shape intended for hole piercing of a certain (required) diameter can be possible only in reducing the hole diameter for electrolyte pumping. It can be supposed in advance that reducing the flow cross section in the cathode-tool will lead to increasing the hydrodynamic losses of the electrolyte flow. Their assessment is presented by the results of the boundary calculations of the mode parameter area (Figure 2). To compare visually the calculation results, Figure 3 presents the data on the mode parameter measurement, which are given in Paper [10].The conditions of the electrochemical piercing presented in Figures 2 and 3 differ only in one parameter of the cathode-tool, namely its hole diameter. The calculations showed that reducing the diameter of the electrolyte flow section increased the inertia moment and reduced the oscillation amplitude of the cathode-tool by $16 \%$, respectively. Increased hydrodynamic losses in this area of the hydraulic path led to a considerable reduction in the mode parameters area which provide the hole electrochemical piercing of a minimal depth $(0.1 \mathrm{~mm})$ even at a "zero" thickness of the electro-isolation layer. In this case we can observe a sharp decrease in the level of maximum achievable depths of piercing from 60 mm (Figure 3, a) to $10 \mathrm{~mm}$ (Figure 2, a). A more considerable transformation in the mode parameters area during the electrochemical piercing of deep holes can be observed in using the cathode-tools of the increased rigidity with the electro-isolation layer thickness $\Delta_{\text {is }}=$ $0.02 \mathrm{~mm}$ (Figure 2, b) and $\Delta_{\text {is }}=0.05 \mathrm{~mm}$ (Figure 2, c). In this case, the narrowing of the mode parameters area, the distortion of the boundary shape and the reduction in the level of the maximum achievable depths of holes machining take place.

Thus, the action of hydrodynamic limitations caused by the narrowing of the side interelectrode gap because of the presence of the electro-isolation layer on the side surface of the cathode - tool as well as reducing the limitations in increasing the tubular electrode 

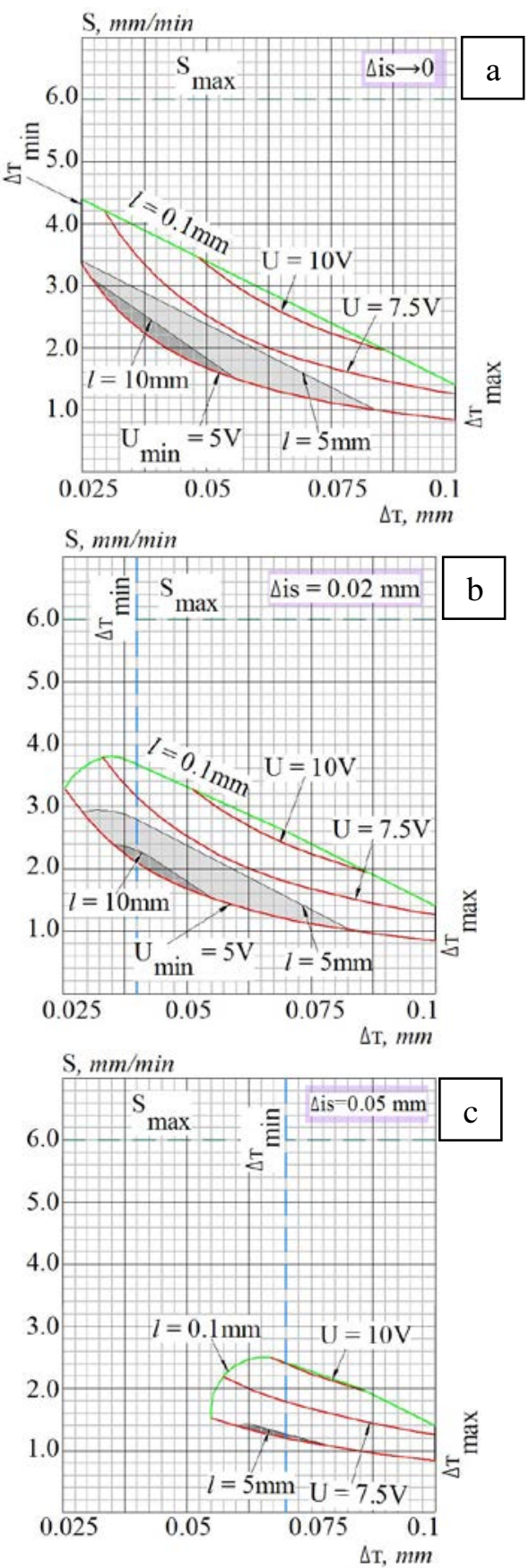

Fig. 2. Calculation of the boundaries of the mode parameters areas of the hole electrochemical piercing in copper M1 in 20\% $\mathrm{NaNO}_{3}$ by a hollow cathode-tool with a diameter ratio of $0.28 / 0.1125 \mathrm{~mm}$ and the lines of the maximum achievable depths of machining at a thickness of an isolation layer: a - $\Delta_{\text {is }} \rightarrow 0$; b - $\Delta_{\text {is }}=0,02 \mathrm{~mm}$; c $-\Delta_{\text {is }}=0,05 \mathrm{~mm}$
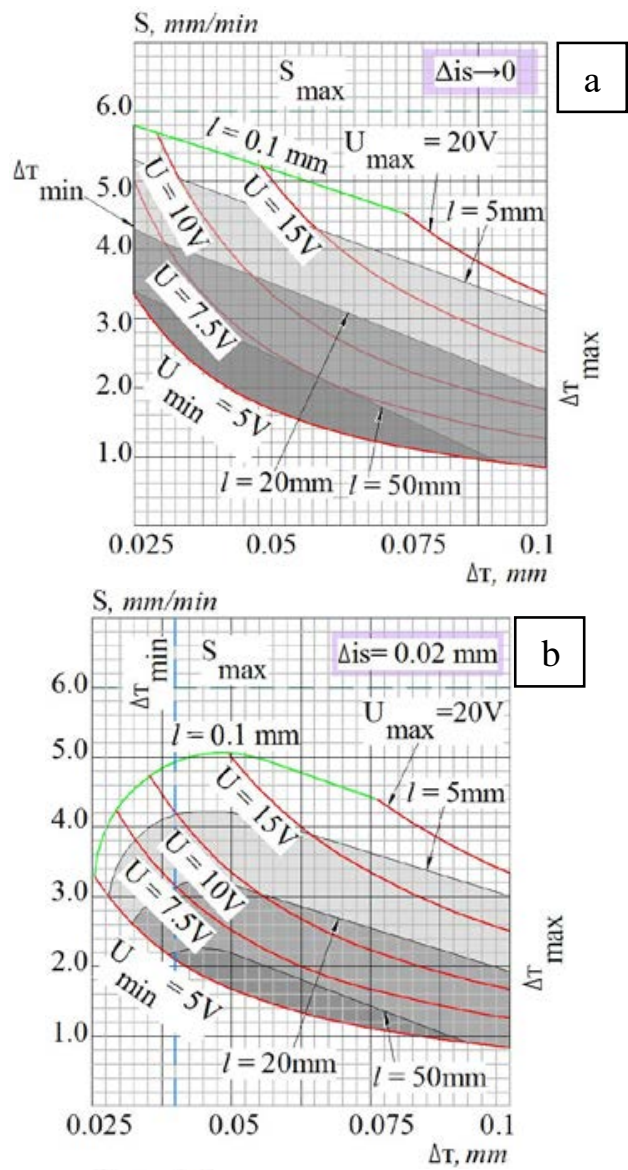

$\mathrm{S}, \mathrm{mm} / \mathrm{min}$

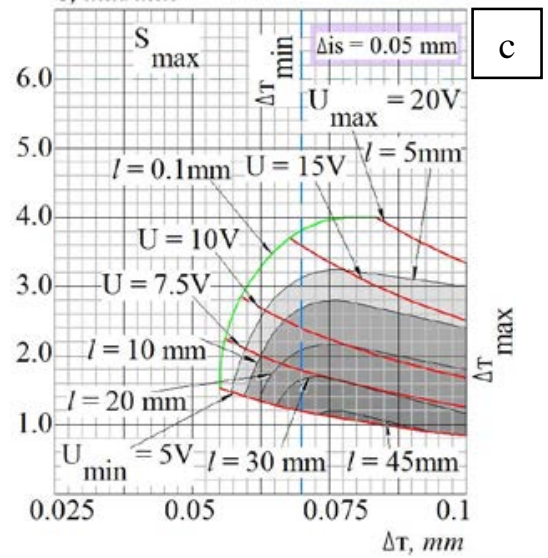

Fig. 3. Calculation of the boundaries of the mode parameters areas of the hole electrochemical piercing in copper $\mathrm{M} 1$ in $20 \% \mathrm{NaNO}_{3}$ by a hollow cathode-tool with a diameter ratio of $0.28 / 0.18 \mathrm{~mm}$ and the lines of the maximum achievable depths of machining at a thickness of an isolation layer: a - $\Delta_{\text {is }} \rightarrow 0$; b - $\Delta_{\text {is }}=0,02 \mathrm{~mm}$; c - $\Delta_{\text {is }}=0,05 \mathrm{~mm}$ 
rigidity should also be taken into account during the combined electro-erosion electrochemical machining, implemented according to the same technological scheme of the hole piercing.

Figure 4 presents the calculation scheme of setting the mode parameters for the electrochemical piercing of a hole with a diameter of $0.57 \mathrm{~mm}$ in stainless steel $12 \mathrm{X} 18 \mathrm{H} 10 \mathrm{~T} .5 \%$ aqua solution of sodium nitrate was used as an electrolyte. Machining was carried out at a technological voltage of $10 \mathrm{~V}$ and an excessive electrolyte pressure of 0.8 $\mathrm{MPa}$. The tubular electrode with a ratio of outside and inside diameters of $0.46 / 0.26 \mathrm{~mm}$ was employed as a cathode-tool. The tool side has no isolation layer, therefore the value in calculations was taken as $\Delta_{\text {is }}=0 \mathrm{~mm}$. According to the methods of setting the mode parameters of the electrochemical piercing presented in Paper [3], the value of the interelectrode gap $\Delta_{\text {Test. }}=\frac{D_{\text {hole }}-D_{K}}{2}=0.055 \mathrm{~mm}$ can be calculated. Taking into consideration the mode parameters of machining (the technological voltage and the electrolyte concentration), we can set the value of the cathode-tool supply equal to $\mathrm{S}=0.6$ $\mathrm{mm} / \mathrm{min}$. (Figure 4).

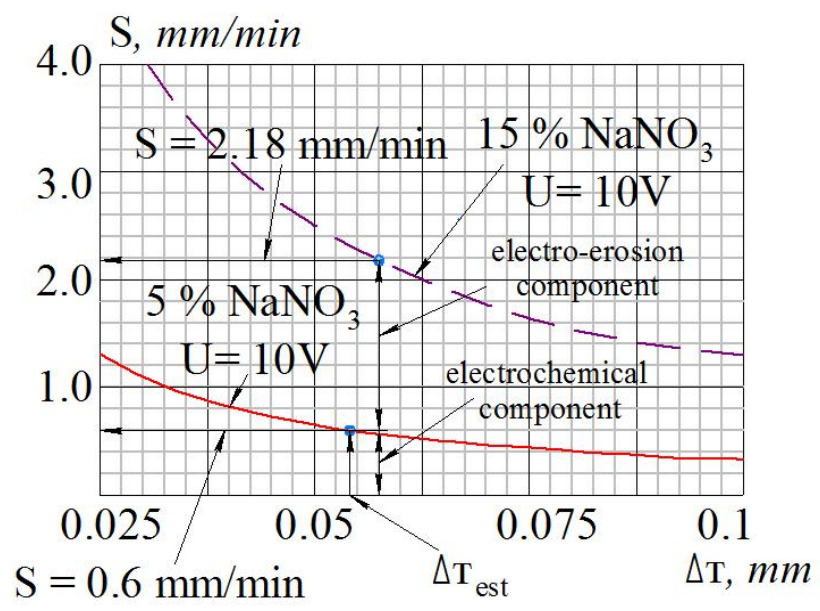

Fig. 4. Scheme of setting the mode parameters of the hole electrochemical piercing $\varnothing 0.57 \mathrm{~mm}$ in stainless steel $12 \mathrm{X} 18 \mathrm{H} 10 \mathrm{~T}$ by a cathode-tool $\varnothing 0.46 / 0.26 \mathrm{~mm}$

The implementation of the electro-erosion component in the combined machining allowed using additional mechanisms during processing. For instance, the implementation of high-voltage pulses with an amplitude of $300 \mathrm{~V}$, a duration of $4 \mu \mathrm{s}$ and a pulse repetition period of $27.5 \mu \mathrm{s}$ in the inter-electrode gap during the electrochemical machining provided forming the hole by the same cathode-tool at a supply $\mathrm{S}=2.18 \mathrm{~mm} / \mathrm{min}$. Therefore, the implementation of high-voltage pulses in the electrochemical processing allowed increasing the piercing efficiency by 3.6 times. It is possible to obtain the same efficiency in electrolytes with a higher electric conductivity during the electrochemical machining. In this case, the electrolyte of sodium nitrate with 15\% concentration can be used (Figure 4). 


\section{Conclusions}

Thus, the combined machining gives the possibility to achieve the same characteristics in using less aggressive technological media, which is considered as a favorable factor both for the technological equipment and for the maintenance staff.

\section{References}

1. V.V. Lyubimov, V.K. Sundukov, Sovremennye sposoby elektrofiziko - himicheskoj obrabotki mikro - i makroob"ektov [Modern methods of electrophysical and chemical processing of micro - and macroobjects], Sovremennye naukoemkie tekhnologii Modern high technologies, no. 1, PP. 77 - 79 (2004).

2. A.B. Zhogolev, Elektrohimicheskoe mikroformoobrazovanie mikrodetalej tipa tel vrashcheniya: diss. ... kand. tekhn. nauk, Tula, 140 (2005).

3. T. Masuzawa, Micro - EDM // Proc. Intern. Symp. Electrical Mach. Bilbao, Spain, 2001.

4. W. Koch, Ehrfeld, F. Michel, Recent progress in micro-electro discharge machining, Part 1, Technology, Proc. Intern. Symp. Electrical machining. Bilbao, Spain, PP. 117 127 (2001).

5. B.N. Zolotykh., Modern physical Theory of Metals Electric Erosion as the Basis for the Deve-lopment of New Trends in EDM, Proc. Intern. Symp. Electromach. (ISEM-XI) Switzerland, Lausanne. PP. 114 - 116 (1995).

6. B.P. Saushkin, Kombinirovannye metody obrabotki v mashinostroitel'nom proizvodstve [Combined processing methods in engineering production], Metalloobrabotka, no. 1(13), PP. 8 - 17 (2003), (In Russian).

7. K.V. Takuntsev, A.N. Zaitsev, Jelektrojerozionno - jelektrohimicheskaja obrabotka: sovremennoe sostojanie, problemy, perspektivy [Electroerosion-electrochemical treatment: current state, problems, prospects], Perspektivnye tehnologii fiziko himicheskoj razmernoj obrabotki i formirovanija jekspluatacionnyh svojstv metallov i splavov [Perspektivnye tehnologii fiziko - himicheskoj razmernoj jekspluatacionnyh formirovanija i obrabotki metallov i splavov svojstv], Ufa, PP. 9 - 13 (2001).

8. Kh.M. Rakhimyanov, I.A. Leontyev, S.I. Vasilevskaya, Tehnologicheskie perspektivy kombinirovanija jelektrojerozionnyh i jelektrohimicheskih processov $v$ obrabotke otverstij malogo diametra [Technological prospects of the combined electroerosion and electrochemical processes in the machining of small-diameter holes], Naukoemkie tehnologii $v$ mashinostroenii - Science intensive technologies in mechanical engineering, 2016, no. 10 (64), PP. 7-13, (In Russian).

9. Kh.M. Rakhimyanov, S.I. Vasilevskaya Prospects of combining electro-erosive and electrochemical processes in forming the holes of a small diameter in difficult - to process materials // Matec Web of Conferences, 2018. - Vol. 224: International conference on modern trends in manufacturing technologies and equipment (ICMTMTE 2018). - Art. 01013 (7p.).

10. Kh.M. Rakhimyanov, S.I. Vasilevskaya, K.Kh. Rakhimyanov Tekhnologicheskie ogranicheniya $v$ elektrohimicheskoj proshivke otverstij malogo diametra [Technological limitations in the electrochemical deep hole drilling of small diameter]. Vestnik Kuzbasskogo gosudarstvennogo tekhnicheskogo universiteta - Bulletin of the Kuzbass state technical university, 2018, no. 4, PP. 5 - 15, (In Russian). Doi: 10.26730/1999 $4125-2018-4-5-15$. 